УДК 619:591.27

(C) 2015

Киричко Б. П., доктор ветеринарних наук,

Звенігородська Т. В., кандидат ветеринарних наук,

Семіренко В. В., аспірант

(науковий керівник - доктор ветеринарних наук Б. П. Киричко)

Полтавська державна аграрна академія

\title{
КІЛЬКІСТЬ І ВИДИ МІКРООРГАНІЗМІВ ЗА ХІРУРГІЧНОЇ ІНФЕКЦЇ̈ У СВИНЕЙ
}

\section{Рецензент - доктор ветеринарних наук В. П. Бердник}

У матеріалах статті наведені дані стосовно спектру мікрофлори свиней, хворих на запальні та запальногнійні прочеси. Вік тварин від двох місяиів до 2,5 років. Породи - велика біла та ландрас. Встановлено, щчо в осередках гнійного запалення найчастіше та у більш високій концентрації виявляли Actinobacillus actinomycetem comitans ma Staphylococcus aureus. $3 i$ слизової носової порожнини під час запальних процесів у свиней найчастіше ізолювали Escherichia coli. B урогенітальному тракті переважали Cатрylobacter coli, Escherichia coli ma Candida albicans.

Ключові слова: свині, мікрофлора, запальногнійні прочеси.

Постановка проблеми. У практиці ветеринарної хірургії хвороби запально-гнійного характеру реєструють у $6,0-22,0 \%$ свиней. Основні серед них - це хвороби кінцівок, рани, хірургічна інфекція тощо. 3 цієї причини вибраковують $20,0-26,0 \%$ племінного та 2,7-6,4 \% товарного свинопоголів'я 3 утратою 12,0-14,0 \% шкірсировини і м'яса [4].

Аналіз останніх досліджень і публікацій, у яких започатковано розв'язання проблеми. Особлива увага до хірургічної інфекції зумовлена складністю її перебігу, нерідко з несприятливим прогнозом, що призводить до економічних збитків.

Причиною виникнення хірургічної інфекції $\mathrm{\epsilon}$ високий ступінь травматизму за сучасних технологій утримання свиней, зниження їхньої імунної реактивності, наявність поліінфекції, порушення правил асептики-антисептики та умов їх утримання $[1,3]$.

Для успішної боротьби з хворобами, розроблення сучасних засобів і методів лікування необхідно з'ясувати повний етіологічний спектр, серед якого патогенна й умовно-патогенна мікрофлора.

Одним із найсучасніших діагностичних тестів для виявлення й ідентифікації мікроорганізмів $\epsilon$ полімеразна ланцюгова реакція (ПЛР). ПЛР оп- тимально поєднує високу чутливість і специфічність, і за цими параметрами традиційні мікробіологічні та імунологічні методи [2].

Мета дослідження: дослідити видовий і кількісний склад мікроорганізмів, ізольованих від свиней, хворих на запальні та гнійно-запальні процеси.

Матеріали і методи дослідження. Об'єктом дослідження була гнійно-запальна патологія дистального відділу кінцівок дорослих свиней (артрити, абсцеси, нориці, виразки підошви копитець, флегмони вінчика в стадії абсцедування), а також хвороби із симптомами запалення респіраторного та урогенітального трактів (табл. 1).

Від хворих тварин відбирали матеріал безпосередньо з осередку гнійного запалення, а також виділення із носової порожнини, піхви, навколоплідну рідину [2]. Матеріал відбирали в одноразові стерильні пробірки, поміщали у спеціальний контейнер та направляли для дослідження.

Якісний i кількісний склад мікроорганізмів був досліджений методом ПЛР з використанням систем: Collection Kit for Upper Respiratory Tract Infectious Agents, Urine-Based Candida albicans PCR Detection Kit, Detection and Identification of Actinobacillus by Multiplex PCR, Multiplex PCR assay for the detection and quantification of Campylobacter spp., Escherichia coli. Дослідження проведені за грандом The Sainsbury Laboratory (Великобританія).

Результати досліджень. Враховуючи значне поширення запально-гнійних уражень дистального відділу кінцівок серед поголів'я свиней, було проведено відбір зразків патологічного матеріалу для ідентифікації мікроорганізмів - одного з етіологічних чинників виникнення й розвитку патології. Для повноти картини відбір зразків проводили безпосередньо з осередка запалення, а також слизових носової порожнини i слизової піхви під час запальних захворювань. 
ВЕТЕРИНАРНА МЕДИЦИНА

\section{1. Характеристика тварин, від яких відбирали проби патологічного матеріалу}

\begin{tabular}{|c|c|c|c|c|c|c|}
\hline $\begin{array}{c}\text { № } \\
\text { зраз- } \\
\text { ка } \\
\end{array}$ & Вік & Стать & \begin{tabular}{|c|} 
Жива \\
маса тіла, \\
кг \\
\end{tabular} & Порода & $\begin{array}{c}\text { Вид патологічного } \\
\text { матеріалу }\end{array}$ & Діагноз \\
\hline 1 & 4 мiс. & свиня & 60 & Велика біла & Гнійний ексудат & $\begin{array}{c}\text { Артрит стрибального сугло- } \\
\text { бу лівої тазової кінцівки }\end{array}$ \\
\hline 2 & 2 міс. & свиня & 25 & Велика біла & Гнійний ексудат & $\begin{array}{l}\text { Абсцес ділянки гомілки } \\
\text { правої тазової кінцівки }\end{array}$ \\
\hline 3 & $2 \mathrm{p}$. & свиня & 180 & Велика біла & $\begin{array}{c}\text { Виділення з носової } \\
\text { порожнини }\end{array}$ & $\begin{array}{c}\text { Гострий риніт. } \\
\text { Деформація копитець } \\
\text { тазових кінцівок } \\
\end{array}$ \\
\hline 4 & $2 \mathrm{p}$. & свиня & 195 & Велика біла & $\begin{array}{c}\text { Виділення слизової } \\
\text { піхви }\end{array}$ & $\begin{array}{l}\text { Патологічні роди. } \\
\text { Вульвовагініт }\end{array}$ \\
\hline 5 & $1,8 \mathrm{p}$ & свиня & 170 & Велика біла & Гнійний ексудат & $\begin{array}{c}\text { Нориця в ділянці вінчика } \\
\text { правої тазової кінцівка }\end{array}$ \\
\hline 6 & 4 мiс. & свиня & 63 & Ландрас & $\begin{array}{c}\text { Виділення слизової } \\
\text { піхви }\end{array}$ & $\begin{array}{c}\text { Виразка в ділянці скакально- } \\
\text { го суглобу лівої тазової } \\
\text { кінцівки }\end{array}$ \\
\hline 7 & 5 міс. & свиня & 80 & Велика біла & $\begin{array}{c}\text { Виділення з носової } \\
\text { порожнини }\end{array}$ & $\begin{array}{c}\text { Виразка в ділянці вінчика } \\
\text { правої тазової кінцівки }\end{array}$ \\
\hline 8 & $2 \mathrm{p}$. & свиня & 185 & Ландрас & Навколоплідні води & Аборт \\
\hline 9 & 5 міс. & свиня & 75 & Велика біла & Гнійний ексудат & $\begin{array}{c}\text { Артрит вінцевого суглобу } \\
\text { лівої тазової кінцівки }\end{array}$ \\
\hline 10 & $2 \mathrm{p}$. & свиня & 200 & Велика біла & Гнійний ексудат & $\begin{array}{c}\text { Флегмона вінчика } \\
\text { лівої тазової кінцівки }\end{array}$ \\
\hline 11 & 4 міс. & свиня & 65 & Велика біла & $\begin{array}{c}\text { Виділення з носової } \\
\text { порожнини }\end{array}$ & $\begin{array}{c}\text { Абсцес у ділянці гомілки } \\
\text { правої тазової кінцівки. } \\
\text { Гострий риніт } \\
\end{array}$ \\
\hline 12 & 2,5 міс. & свиня & 38 & Велика біла & Гнійний ексудат & $\begin{array}{c}\text { Виразка підошви копитця } \\
\text { лівої тазової кінцівки }\end{array}$ \\
\hline 13 & 5 мiс. & свиня & 90 & Ландрас & $\begin{array}{c}\text { Виділення з носової } \\
\text { порожнини }\end{array}$ & Бронхопневмонія \\
\hline 14 & $1,9 \mathrm{p}$ & свиня & 180 & Велика біла & $\begin{array}{c}\text { Виділення слизової } \\
\text { піхви }\end{array}$ & $\begin{array}{c}\text { Вульвовагініт. Тріщини ко- } \\
\text { питцевого рогу лівої тазової } \\
\text { кінцівки }\end{array}$ \\
\hline 15 & $2 \mathrm{p}$. & свиня & 170 & Ландрас & $\begin{array}{c}\text { Виділення слизової } \\
\text { піхви }\end{array}$ & $\begin{array}{l}\text { Затримка посліду. } \\
\text { Вульвовагініт }\end{array}$ \\
\hline 16 & $1,6 \mathrm{p}$ & свиня & 200 & Велика біла & $\begin{array}{c}\text { Виділення з носової } \\
\text { порожнини }\end{array}$ & Гострий риніт \\
\hline 17 & $1,8 \mathrm{p}$ & кнур & 210 & Ландрас & $\begin{array}{c}\text { Виділення з носової } \\
\text { порожнини }\end{array}$ & Гострий риніт \\
\hline 18 & $1,8 \mathrm{p}$ & свиня & 180 & Велика біла & $\begin{array}{c}\text { Виділення слизової } \\
\text { піхви }\end{array}$ & $\begin{array}{c}\text { Затримка посліду. } \\
\text { Вульвовагініт }\end{array}$ \\
\hline 19 & $2,5 \mathrm{p}$ & свиня & 190 & Велика біла & $\begin{array}{c}\text { Виділення з носової } \\
\text { порожнини }\end{array}$ & Хронічна бронхо-пневмонія \\
\hline 20 & $2 \mathrm{p}$. & свиня & 165 & Ландрас & $\begin{array}{c}\text { Виділення з носової } \\
\text { порожнини }\end{array}$ & Хронічна бронхо-пневмонія \\
\hline
\end{tabular}

У результаті встановлено, що за хірургічної патології з осередків запалення (табл. 2) у $83 \%$ були ідентифіковані Actinobacillus actinomycetem comitans та Staphylococcus aureus, y $67 \%-E s-$ cherichia coli та Actinobacilus israelii. Рідше виявляли Streptococcus pyogenes, Kingella kingae, Streptococcus intermedius, Proteus vulgaris та Fusobacterium necrophorum. 
ВЕТЕРИНАРНА МЕДИЦИНА

\section{2. Види і кількість мікроорганізмів, виявлених з осередків гнійного запалення, $\lg$ КУО}

\begin{tabular}{|c|c|c|c|c|c|c|c|c|c|}
\hline $\begin{array}{c}\text { № дослідже- } \\
\text { ного зразка }\end{array}$ & $\begin{array}{c}\text { Actinobacillus } \\
\text { actinomycetem } \\
\text { comitans }\end{array}$ & $\begin{array}{c}\text { Actinobacilus } \\
\text { israelii }\end{array}$ & $\begin{array}{c}\text { Kingella } \\
\text { kingae }\end{array}$ & $\begin{array}{c}\text { Strepto- } \\
\text { coccus } \\
\text { pyogenes }\end{array}$ & $\begin{array}{c}\text { Staph. } \\
\text { aureus }\end{array}$ & $\begin{array}{c}\text { Strepto- } \\
\text { coccus } \\
\text { intermedius }\end{array}$ & $\begin{array}{c}\text { Esche } \\
\text { richia } \\
\text { coli }\end{array}$ & $\begin{array}{c}\text { Proteus } \\
\text { vulgaris }\end{array}$ & $\begin{array}{c}\text { Fusobac- } \\
\text { terium } \\
\text { necroph } \\
\text { orum }\end{array}$ \\
\hline 1 & 10,5 & 4,2 & 3,8 & - & 4,2 & - & - & - & - \\
\hline 2 & 9,6 & 2,2 & - & 3,6 & 8,5 & 2,2 & 3,6 & - & 4,5 \\
\hline 5 & 4,6 & - & 6,2 & 3,8 & 4,7 & 5,3 & 3,2 & 4,0 & 4,3 \\
\hline 9 & - & - & 5,6 & 5,3 & 4,3 & - & - & - & - \\
\hline 10 & 6,5 & 3,8 & - & - & - & - & 2,6 & - & - \\
\hline 12 & 11,4 & 6,5 & - & - & 6,2 & 5,8 & 6,4 & 5,2 & - \\
\hline
\end{tabular}

3. Види і кількість мікроорганізмів, виділених зі слизової оболонки носової порожснини, lg КУО

\begin{tabular}{|c|c|c|c|c|c|c|c|c|c|c|c|}
\hline $\begin{array}{c}\text { № дослід- } \\
\text { женого } \\
\text { зразка }\end{array}$ & $\begin{array}{c}\text { Actinoba } \\
\text { cillus } \\
\text { actinom. } \\
\text { comitans }\end{array}$ & $\begin{array}{c}\text { Actinobacil } \\
\text { lus } \\
\text { pleuropneu } \\
\text { moniae }\end{array}$ & $\begin{array}{c}\text { Campylo } \\
\text { bacter } \\
\text { coli }\end{array}$ & $\begin{array}{c}\text { Streptoc } \\
\text { occus } \\
\text { pyogenes }\end{array}$ & $\begin{array}{c}\text { Staph. } \\
\text { aureus }\end{array}$ & $\begin{array}{c}\text { Str. } \\
\text { inter } \\
\text { medi } \\
\text { us }\end{array}$ & $\begin{array}{c}\text { Str. } \\
\text { mitis }\end{array}$ & $\begin{array}{c}\text { E. } \\
\text { coli }\end{array}$ & $\begin{array}{c}\text { Proteus } \\
\text { vulgaris }\end{array}$ & $\begin{array}{c}\text { Candida } \\
\text { albicans }\end{array}$ & $\begin{array}{c}\text { Haemo- } \\
\text { philus } \\
\text { parasuis }\end{array}$ \\
\hline 3 & 4,3 & 3,6 & 3,2 & - & 4,2 & - & - & 4,3 & - & 5,4 & - \\
\hline 7 & - & 2,4 & 4,2 & - & 3,6 & 2,6 & - & 3,7 & 2,1 & 3,6 & 2,4 \\
\hline 11 & - & - & 3,4 & 2,8 & 3,6 & - & - & 3,7 & 3,4 & - & 3,1 \\
\hline 13 & 3,6 & 2,5 & - & 2,5 & 4,9 & 4,1 & 2,2 & 5,2 & - & - & - \\
\hline 16 & 5,6 & - & 5,2 & - & - & - & - & 4,4 & - & 5,2 & - \\
\hline 17 & 2,5 & - & - & 4,6 & 3,6 & 2,5 & 3,2 & 5,0 & - & - & - \\
\hline 19 & - & - & 5,2 & 2,5 & - & 2,4 & - & 2,6 & 2,7 & 6,4 & 4,4 \\
\hline 20 & - & 3,3 & 4,9 & - & 3,7 & - & - & 3,4 & - & 4,8 & - \\
\hline
\end{tabular}

4. Види і кількість мікроорганізмів, ідентифікованих зі слизової піхви, Іg КУО

\begin{tabular}{|c|c|c|c|c|c|c|c|c|c|c|c|}
\hline $\begin{array}{c}\text { № дослід- } \\
\text { женого } \\
\text { зразка }\end{array}$ & $\begin{array}{c}\text { Actinob } \\
\text { acillus } \\
\text { actinom. } \\
\text { comitans }\end{array}$ & $\begin{array}{c}\text { Kingella } \\
\text { kingae }\end{array}$ & $\begin{array}{c}\text { Campy- } \\
\text { lobacter } \\
\text { coli }\end{array}$ & $\begin{array}{c}\text { Str. } \\
\text { pyogenes }\end{array}$ & $\begin{array}{c}\text { Staph. } \\
\text { aureus }\end{array}$ & $\begin{array}{c}\text { Str. } \\
\text { inter } \\
\text { medi } \\
\text { us }\end{array}$ & $\begin{array}{c}\text { Str. } \\
\text { mitis }\end{array}$ & $\begin{array}{c}\text { E. } \\
\text { coli }\end{array}$ & $\begin{array}{c}\text { Proteus } \\
\text { vulgaris }\end{array}$ & $\begin{array}{c}\text { Candida } \\
\text { albicans }\end{array}$ & $\begin{array}{c}\text { Actino } \\
\text { bacilus } \\
\text { israelii }\end{array}$ \\
\hline 4 & - & 2,4 & 5,6 & 2,3 & 3,2 & - & - & 5,3 & 3,6 & 10,6 & - \\
\hline 6 & - & - & 7,2 & - & - & - & - & 6,2 & - & 4,2 & - \\
\hline 8 & - & - & 2,3 & - & - & - & - & - & - & 2,4 & - \\
\hline 14 & 3,6 & - & 3,4 & 2,6 & 4,2 & - & 2,1 & 3,2 & - & 2,4 & 3,0 \\
\hline 15 & 2,8 & 2,5 & 4,5 & - & 3,9 & 3,4 & 2,5 & 3,9 & 2,6 & - & 2,6 \\
\hline 18 & - & - & 5,2 & 3,1 & - & - & - & 3,7 & - & 11,3 & - \\
\hline
\end{tabular}

Зі слизової оболонки носової порожнини хворих свиней (табл. 3) були виділені:

- Escherichia coli (у 100 \% випадків);

- Staphylocjccus aureus, Campylobacter coli (75\% випадків);

- Candida albicans (у 62,5 \% випадків);

- Streptococcus pyogenes, Streptococcus intermedius, Actinobacillus actinomycetem comitans, Actinobacillus pleuropneumoniae (у $50 \%$ досліджених зразків);

- рідше - Proteus vulgaris, Haemophilus parasuis та Streptococcus mitis.
Зі слизової піхви хворих свиней (табл. 4) були ідентифіковані:

- Campylobacter coli (100 \% випадків);

- Escherichia coli і Candida albicans (83\% випадків);

- Streptococcus pyogenes i Staphylococcus aureus (у $50 \%$ досліджених зразків).

Значно рідше виділяли Actinobacillus actinomycetem comitans, Kingella kingae, Actinobacilus israelii, Proteus vulgaris, Streptococcus mitis та Streptococcus intermedius. 


\section{ВЕТЕРИНАРНА МЕДИЦИНА}

Висновки: 1. В осередках гнійного запалення найчастіше та у більш високій концентрації виявляли Actinobacillus actinomycetem comitans та Staphylococcus aureus.

2. Зі слизової носової порожнини під час за-

\section{БІБЛІОГРАФІЯ}

1. Ільніцький М. Г. Патогенетичне обгрунтування засобів детоксикаційної терапії та профілактики ранової інфекції у свиней : автореф. дис. на здобуття наук. ступеня д. вет. н. : спец. 16.00 .05 «Ветеринарна хірургія» / М. Г. Ільніцький - Б. Церква, 2002. - 39 с.

2. Микробиологические и вирусологические методы исследований в ветеринарной медицине : [справочное пособие] / [Головко А. Н., Ушкалов В. А., Скрыпник В. Г. и др.] ; под ред. акад. А. Н. Головко. $-\mathrm{X}$. : «HTMT», 2007. -512 c. пальних процесів у свиней найчастіше ідентифікували Escherichia coli.

4. В урогенітальному тракті переважали Campylobacter coli, Escherichia coli та Candida albicans.

3. Общая ветеринарная хирургия / [Лебедев А. В., Лукьяновский В. А., Семенов Б. С. и др.] ; под ред. А. В. Лебедева, В. А. Лукьяновского, Б. С. Семенова. - М. : Колос, 2000. - 488 с.

4. Рубленко М. В. Патогенетичні особливості запальної реакції у свиней при хірургічних хворобах та методи їх лікування : автореф. дис. на здобуття наук. ступеня д. вет. н. : спец. 16.00.05 «Ветеринарна хірургія» / М. В. Рубленко. - Б. Церква, 2000. -35 с. 